\title{
Effect of supplementation with organic acids on productive and reproductive parameters in guinea pigs
}

\author{
Efecto de la suplementación con ácidos orgánicos sobre parámetros \\ productivos y reproductivos en cuyes
}

Christian Vela Espinoza ${ }^{1}$; Siever Morales-Cauti ${ }^{2}$

\begin{tabular}{ll}
\hline \multicolumn{1}{c}{ ARTICLE DATA } \\
\hline 1 Research, MVZ, Universidad Científica del Sur, \\
Lima, Perú, christian_01028@hotmail.com. \\
2 Professor, M.Sc., Universidad Científica del Sur, \\
Universidad Nacional Mayor de San Marcos, Lima, \\
Perú, sieverm@hotmail.com..
\end{tabular}

Cite: Vela, C.; Morales-Cauti, S. (2020). Effect of supplementation with organic acids on productive and reproductive parameters in guinea pigs. Revista de Ciencias Agrícolas. 37(1): 51-58.

doi: https://doi.org/10.22267/rcia.203701.131

Received: June 282019.

Accepted: March 262020.

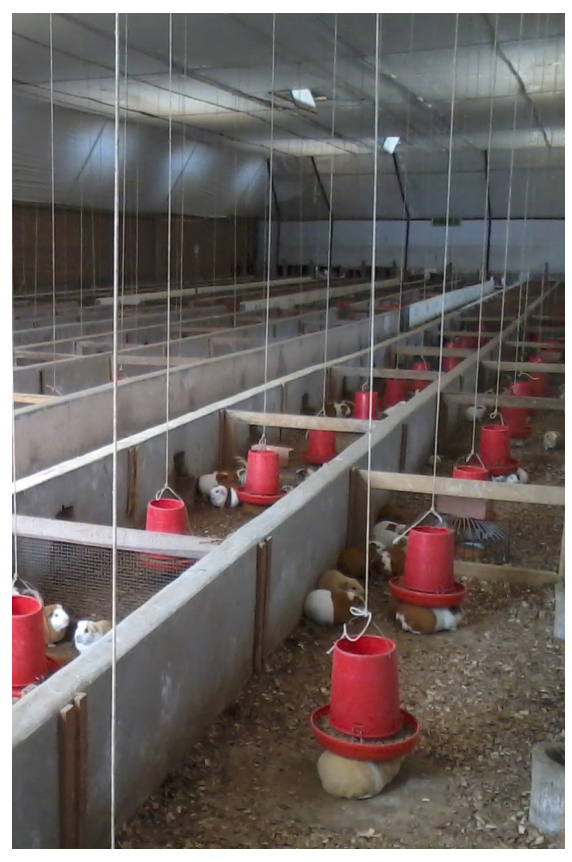

ABSTRACT

Guinea pig production systems demand organic alternatives to improve their productivity, due to the increased demands of this type of livestock operations. The present study aimed to evaluate the effect of organic acids on the productive and reproductive indices in reproductive Guinea pigs in an intensive breeding farm in Lima. 60 pools were used with 10 Guinea pigs in each one ( 9 females and one male). They were randomly divided into 4 treatment groups: T1: $1 \mathrm{~mL} / \mathrm{L}, \mathrm{T} 2: 2 \mathrm{~mL} / \mathrm{L}, \mathrm{T} 3$ : $4 \mathrm{~mL} / \mathrm{L}$; all with 15 pools in total (5 pools each with dosage of 5, 10 and 15 days, respectively), and T4: Control (15 pools without dosage); the observation period was 3 months. No significant difference was found ( $p>0.05$ ) between treatments for weight gain, percentage of maternal mortality, percentage of abortions, percentage of pregnancy, number of offspring born and percentage of viability. For the percentage of mortality of pups and average weight of the offspring, a significant difference was found ( $\mathrm{p}<0.05)$, demonstrating that T3 reached a higher weight index at birth of offspring (T3: 147.7 / 142.7 / 146.8g) and lower percentage of mortality in rabbits (T3: 0 / 1.8 / 3.0\%). No significant difference was found in terms of dosing days. It is concluded that supplementation with organic acids with $\mathrm{T} 3(4 \mathrm{~mL} / \mathrm{L})$ improved the weight at birth of the offspring and the mortality percentage in kits.

Keywords: citric acid; phosphates; efficiency; mortality; morbidity (Source: $\mathrm{MeSH}$ ).

\section{RESUMEN}

Los sistemas de producción de cuyes demandan alternativas orgánicas para mejorar su productividad, debido al incremento de las exigencias de este tipo producción pecuaria. El presente estudio tuvo como objetivo evaluar el efecto de ácidos orgánicos sobre los índices productivos y reproductivos en cuyes reproductores en una granja de crianza intensiva en Lima. Se utilizó 60 pozas con 10 cuyes en cada una (9 hembras y un 
macho) y se dividieron aleatoriamente en 4 grupos de tratamiento, T1: 1mL/L, T2: $2 \mathrm{~mL} / \mathrm{L}, \mathrm{T} 3: 4 \mathrm{~mL} / \mathrm{L}$; todos con 15 pozas en total (5 pozas cada una con dosificación de 5, 10 y 15 días, respectivamente), y el T4: Control (15 pozas sin dosificación); el periodo de observación fue de 3 meses. No se encontró diferencia significativa ( $>0.05$ ) entre tratamientos tanto para ganancia de peso, porcentaje de mortalidad de madres, porcentaje de abortos, porcentaje de preñez, número de crías nacidas y porcentaje de viabilidad. Para el porcentaje de mortalidad de gazapos y peso promedio al nacimiento de las crías, se encontró diferencia significativa ( $<<0.05)$, demostrándose que el T3 alcanzó un mayor índice de peso al nacimiento de crías (T3: 147,7 / 142,7 / 146,8g) y menor porcentaje de mortalidad en gazapos (T3: 0 / 1,8 / 3,0\%). No se encontró diferencia significativa en cuanto a los días de dosificación. Se concluye que la suplementación con ácidos orgánicos con T3 (4mL/L) mejoró el peso al nacimiento de las crías y el porcentaje de mortalidad en gazapos.

Palabras clave: ácido cítrico; fosfatos; eficiencia; mortalidad; morbilidad (Fuente: MeSH).

\section{INTRODUCTION}

Theguineapig(Caviaporcellus), isaspeciesnative to the Andean area of Peru, Ecuador, Colombia and Bolivia. It is mainly characterized by its low production cost and its high nutritional value; These advantages have favored its exploitation and widespread consumption (Morales-Cauti, 2018). The success of this livestock activity is based on a rigorous control of the productive and reproductive parameters

In recent years, the great demand for guinea pig meat led to the need to develop intensive breeding; unfortunately, this brought problems for the species, increasing susceptibility to bacterial, viral, parasitic and / or metabolic diseases that significantly affect productivity (Matsuura et al., 2010; Morales, 2012; Vargas et al., 2014; Morales-Cauti, 2018); being salmonellosis one of the most important diseases, responsible for significant economic losses (up to 53\% due to morbidity) and 95\% mortality (Morales et al., 2013).

For the treatment of diseases, growth promoting antibiotics (APC) are an alternative as a preventive measure (Gonzáles et al., 2013; Sánchez-Silva et al., 2014); however, improper handling generates problems in animal and public health, linked to residues in animal products and by-products, as well as the risk of causing antibiotic resistance (Upadhaya et al., 2014). This motivated a search for natural alternatives, such as acidifiers, on which various results have been reported on the productive parameters in different animal species (Upadhaya et al., 2014; Xiong et al., 2019).

In this group of acidifiers, the organic acids are safe substances that do not leave residues in animal products (Sánchez-Silva et al., 2014). The term "organic acids" describe a group of short-chain fatty acids, among these are: the Acetic, propionic, butyric, lactic, fumaric, malic, citric, benzoic acid, among others (Waldroup et al., 1995; Bourassa et al., 2018), some of which are related to stimulating effects on the immune system (Liu et al., 2018). According to Upadhaya et al. (2014); the mechanism of action of organic acids seeks to improve intestinal development, the digestibility capacity of nutrients, the development of resistance to diseases (Xiong et al., 2019), the intestinal microbiota, reducing the $\mathrm{pH}$ of the gastrointestinal tract, thus creating a negative environment for the proliferation of pathogenic microorganisms of the genera Escherichia, Clostridium and Salmonella (Liu et al., 2018); and, this is why organic acids have been studied in various species. Therefore, the objective of this study was to evaluate the effectiveness of these additives on the productive and reproductive parameters in guinea pigs. 


\section{MATERIALS AND METHODS}

The study was carried out between August and November, 2017, at the intensive guinea pig breeding farm located in Cerro Azul, in the western part of the Cañete province, south of Lima, Peru; located between the geographic coordinates of $13^{\circ} 02>21$ south and $76^{\circ} 29>21$ western; at an altitude of 3 meters above sea level and a temperature that ranges between 15 to $30^{\circ} \mathrm{C}$ (INEI, 2017).

The population of this study were breed Guinea pigs from a commercial farm, located in the Cerro Azul district, in the reproductive stage. The sample was taken from female and male Guinea pigs at the beginning of breeding. For the sample calculation, the formula was used to test hypotheses in studies that compare the mean of a single sample against another already established mean. Through this, a value of $n$ $=10$ individuals per experimental unit were obtained, that is, nine females and one male per pool (1: 9), housed in breeding pools of $1 \times 1.4 \mathrm{x}$ $0.6 \mathrm{~m}$. In total, 60 pools were worked randomly distributed in four treatment groups.

These pools were distributed in four treatments, with 15 pools (repetitions); which were distributed according to dosing time (for five days, for 10 days and for 15 days). Groups of treatment were: T1: of $1 \mathrm{~mL} / \mathrm{L}, \mathrm{T} 2:$ of $2 \mathrm{~mL} / \mathrm{L}$, T3: of $4 \mathrm{~mL} / \mathrm{L}$ of organic acids diluted in water, and T4: control treatment.

The treatment consisted of supplying the organic acids, in this case citric acid, phosphates, propionates and excipients in the drinking water of the breeding Guinea pigs. This was changed daily until the end of the dosing period. For this, 1 liter of drinking water was used for each pool of the Guinea pigs under study, and it was mixed with the doses established according to the treatments.

The experimental work lasted three months, counting from the first days of the treatment where it was provided according to the treatment group to which they belonged. Regarding the reproductive and productive controls, the data necessary for the parameters established by the study were recorded daily. Identifying the mating pool as an experimental unit.

The values of each dependent variable such as weight gain, mortality in mothers and young, offspring born, abortions, pregnancy percentage, and average birth weight of the offspring were evaluated. These variables, which are of continuous quantitative type, were evaluated based on their type of normal or non-normal distribution, through the multifactor ANOVA test or the Kruskal-Wallis test, respectively. These statistical analyzes were carried out with the software STATA 12.0.

\section{RESULTS AND DISCUSSION}

The initial weights of the animals that participated in the study were similar, resulting in higher in the animals of the control group ( $p>$ $0.05)$, although statistically no such difference was found for the weight gain index, or for the percentage mortality (Table 1). 
Table 1. Average of productive parameters in breeding Guinea pigs in a farm in Cerro Azul.

\begin{tabular}{ccccccc}
\hline Treatments & Dosing days & $\begin{array}{c}\text { Starting } \\
\text { weight }\end{array}$ & $\begin{array}{c}\text { Final } \\
\text { Weight }\end{array}$ & $\begin{array}{c}\text { Weight } \\
\text { gain }\end{array}$ & $\begin{array}{c}\text { Average birth } \\
\text { weight of pups }\end{array}$ & $\begin{array}{c}\text { \% Mortality } \\
\text { of mothers * }\end{array}$ \\
\hline \multirow{2}{*}{ T1 } & 5 & 828.4 & 1562.1 & 733.7 & $134.3 \mathrm{a}$ & 11.8 \\
& 10 & 820.9 & 1567.7 & 746.7 & $132.5 \mathrm{a}$ & 3.3 \\
\multirow{2}{*}{ T2 } & 15 & 818.6 & 1561.6 & 743 & $140.6 \mathrm{a}$ & 14.2 \\
\hline & 5 & 824.2 & 1646.2 & 822 & $139.8 \mathrm{a}$ & 14 \\
& 10 & 812.1 & 1605.4 & 793.2 & $130.1 \mathrm{a}$ & 2.2 \\
T3 & 15 & 799.3 & 1592.4 & 793.1 & $131.7 \mathrm{a}$ & 8.7 \\
\hline Control & 5 & 807.3 & 1600.1 & 792.6 & & 7.3 \\
\hline
\end{tabular}

${ }^{(*)}$ The groups do not have statistically significant differences ( $\left.\mathrm{p}>0.05\right)$. ${ }^{\text {one }} \mathrm{T} 1$ : Water supplemented with $1 \mathrm{~mL} / \mathrm{L}$ of organic acids; T2: Water supplemented with $2 \mathrm{~mL}$ / L of organic acids; T3: Water supplemented with 4mL/L of organic acids; Control: No supplementation.

At the level of reproductive parameters, the mortality rate of $0 \%$ was higher in $\mathrm{T} 3$ at 5 days
( $\mathrm{p}<0.05)$; without this same advantage being reflected in the other parameters (Table 2).

Table 2. Percentage distribution and average data of reproductive parameters in breeding guinea pigs in a farm in Cerro Azul.

\begin{tabular}{ccccccc}
\hline Treatments & $\begin{array}{c}\text { Dosing } \\
\text { days }\end{array}$ & $\begin{array}{c}\text { \% Mortality } \\
\text { of kits }\end{array}$ & \% Abortions * & \% Pregnancy * & $\begin{array}{c}\text { Number } \\
\text { of pups* }\end{array}$ & \% Viability* \\
\hline \multirow{2}{*}{ T1 } & 5 & 0.8 to & 5 & 82.7 & 15.4 & 96.4 \\
& 10 & 0 to & 5 & 68.9 & 7.4 & 100 \\
\hline \multirow{2}{*}{ T2 } & 15 & $2.2 \mathrm{a}$ & 2.9 & 83.3 & 16.2 & 94 \\
\hline & 5 & $2 \mathrm{ab}$ & 5 & 73.3 & 13.2 & 97.6 \\
& 10 & $3.5 \mathrm{ab}$ & 8 & 89.4 & 14 & 100 \\
T3 & 15 & $3.4 \mathrm{ab}$ & 8 & 77.9 & 14.6 & 95 \\
\hline & 10 & $0 \mathrm{a}$ & 0 & 44 & 6.4 & 100 \\
& 15 & 3rd & 2.9 & 70.4 & 11.2 & 94.9 \\
\hline
\end{tabular}

1 T1: Water supplemented with 1mL/L of organic acids; T2: Water supplemented with 2mL/L of organic acids; T3: Water supplemented with $4 \mathrm{~mL} / \mathrm{L}$ of organic acids; Control: No supplementation

a,b,c Different superscripts indicate that the groups present statistically significant difference $(\mathrm{p}<0.05)$

${ }^{*}$ Asterisk after the variable name indicate that the groups do not present statistically significant difference $(p>0.05)$. 
The present study did not find a treatment that shows outstanding results for all the parameters evaluated, making use of organic acids (citric acid, propionates and phosphates) potentially due to the normal conditions of a guinea-pig production system. At the literature level, studies with organic acids in guinea pigs are reported, mainly evaluating productive parameters in breeding guinea pigs (Bazay et al., 2014; Sánchez-Silva et al., 2014; Cano et al., 2016), who evaluate only weight gain, dry matter intake and food conversion index, possibly due to the reported positive influence on intestinal cell proliferation.

In relation to the productive parameters such as weight gain, weights between 733.7 to $824.4 \mathrm{~g}$ were achieved for the reproductive females of the different treatments (Table 1); Regarding the control group (745.4g), treatments 2 and 3 reported higher weights than the control group ( $p>0.05)$. This difference may be due to the fact that the dose of organic acids used presents a positive influence on the assimilation of nutrients and increased metabolism (Suryanarayana et al., 2012; Upadhaya et al., 2014; Ke et al., 2017), influence on the maturity of the villi and intestinal physiology of the species (SánchezSilva et al., 2014; Xiong et al., 2019), as well as in the forage fermentation (Ke et al., 2017). However, this difference was not significant ( $\mathrm{p}>$ 0.05 ) for the 3 treatments, potentially due to the poor monitoring of the weights, due to the condition of pregnant breeders, and the risk of handling that it represents for these animals.

This evaluation took place under normal conditions of intensive coastal breeding, where parameters as mortality in the control group was reported with an index of $15.4 \%$, while for treatment groups 1, 2 and 3 they indicate lower values ( $p>0.05$ ) in a range of 2.2 to $14.2 \%$ (Table 1), similar to that found by Gonzáles et al. (2013), where no difference was found (p> 0.05 ) for the parameters evaluated such as mortality. However, this numerical difference that favors the evaluated treatments could be associated with normal rearing conditions, or with a potential effect of organic acids on pathogen control (Suryanarayana et al., 2012; Bourassa et al., 2018; Dittoe et al., 2018; Grecco et al., 2018).

Regarding the percentage of pregnancy, levels up to $95.2 \%$ are reported for the treatments, and $90.3 \%$ for the control group; Treatment groups 1 and 2 were lower than this, except for treatment 3 with a 15-day supply with $95.2 \%$ ( $p>0.05$ ); and the percentage of abortions with ranges from 0 to $8 \%$ for treatment groups 1,2 and 3 ; and $3.3 \%$ for the control group, where only for treatment 3 , percentages lower than the control ( $p>0.05)$ were reported (Table 2). These reproductive parameters are influenced by multiple factors specific to the species such as the poliestrous character, postpartum heat, body condition, continuous breeding system (Jimenez and Huamán, 2010); since there is evidence of the activity of organic acids on embryonic development (Suryanarayana et al., 2012; Dittoe et al., 2018), despite this, no significant difference was obtained $(p>0.05)$ due to the limitations of the rearing system, evidenced by factors such as poor handling, health and nutrition; All of this generates reproductive disorders such as delayed fertilization, death and embryo reabsorption, and abortions (Morales, 2012; Morales, 2017).

The mortality of kittens, ranges from $0 \%$ to $3.5 \%$ are reported in treatment groups 1, 2 and 3 ; and $5.3 \%$ mortality of rabbits for the control group; For treatments 1 and 3 of 10 and 5 days, respectively, no mortality was reported ( $p<0.05$ ) (Table 2). This potentially could be due to a positive influence on the defense 
mechanisms in these groups (Suryanarayana et al., 2012; Upadhaya et al., 2014; Bourassa et al., 2018; Xiong et al., 2019), because all the groups under evaluation were under normal rearing conditions, they presented the same risk against the pathogens of said farm, and deficiencies in the expression of the immune response of the kits, due to their young age (Chuquizuta and Morales, 2017). These organic acids improve the digestive process, decrease the time and retention of food, increase ingestion, increase the count of beneficial bacteria (Upadhaya et al., 2014; Ruggeri et al., 2018), and prevent diarrheal processes (Suryanarayana et al., 2012), potentially improving the physiological performance of animals.

Regarding the number of calves in the treatment groups, ranges from 6.4 to 16.2 calves per pool were found for treatment groups 1, 2 and 3; Compared with the control group, this is within the range of treatments (11.4), without finding a significant difference ( $p>0.05$ ). The numerical differences between these treatments and the control (Table 2) could be due to an inherent characteristic of the species, since according to Aliaga et al. (2009), show a highly variable condition for this parameter; being potentially affected by both nutritional and genetic factors, to which the mothers in the study are subjected.

For the percentage of viability of rabbits, ranges from 94 to $100 \%$ are reported in this study for treatment groups 1,2 and 3. In relation to the control group (93.9\%), treatments 1, 2, 3 report values higher than the control $(p>0.05)$ (Table 2).It can be stated that although the results are not significant, if there is a numerical difference (Table 2); This can be explained due to the role that organic acids play on young rabbits at birth, although it is possible if there is a direct influence from the mother, it is also possible that these offspring independently have acquired benefits from these substances by ingesting the supplemented water (Grecco et al., 2018); lactating guinea pigs require and ingest $30 \mathrm{cc}$ of water per day. In turn, Aliaga et al. (2009), report values of 60 to $83 \%$ for this parameter, these being also lower than the present study.

Regarding the average weight at birth, ranges are reported for treatment groups 1, 2, and 3, from 130.1 to $147.7 \mathrm{~g}$. Regarding the control group (118.6g), treatment 3 in doses of 5 days obtained the highest value $(147.7 \mathrm{~g})$ compared tos other experimental groups (Table 2). This shows a significant difference $(\mathrm{p}<0.05)$ between treatments, which suggests that if there is a positive effect of these organic acids on the weight with which the kits are born (SánchezSilva et al., 2014; Upadhaya et al., 2014). Saying this, it is possible that the supplementation with these organic acids added to the diet of the pregnant female has had a direct influence ( $p$ $<0.05$ ) on the development of the fetus, finally favoring the weight of the kitten (Guevara et al., 2015; Dittoe et al., 2018).

Therefore, under the conditions of the present study, the results suggest that there is an opportunity to improve the reproductive behavior ofguineapigs with the supplementation of organic acids based on $4 \mathrm{~mL} / \mathrm{L}$ in doses of 5 days. However, as mentioned by Sánchez-Silva et al. (2014), the lack of published experiences on responses to organic acids in guinea pigs, the wide range of experimental conditions in terms of species, the types of acids, the different doses and supplementation methods of the published studies, and the still hypothetical nature of the mechanism of action of organic acids (Dittoe $e t$ al., 2018), somewhat hinders the forcefulness of the results in the other parameters evaluated. 


\section{CONCLUSION}

The group that used the $4 \mathrm{~mL} / \mathrm{L}$ treatment as a supplementation dose with organic acids for five days did not present mortality in rabbits and better average birth weight.

Conflict of interest: The authors declare that there is no conflict of interest.

\section{BIBLIOGRAPHIC REFERENCES}

Aliaga, L.; Moncayo, R.; Rico, E.; Caycedo, A. (2009). Producción de cuyes. Lima, Perú: Editorial de la Universidad Católica Sedes Sapientiae. 808p.

Bazay, G.; Carcelén, F.; Ara, M.; Jiménez, R.; Gonzales, R.; Quevedo, W. (2014). Efecto de los mananooligosacáridos sobre los parámetros productivos de cuyes (cavia porcellus) durante la fase de engorde. Rev Inv Vet Perú. 25(2): 198-204

Bourassa, D.V.; Wilson, K.M.; Ritz, C.R.; Kiepper, B.K.; Buhr, R.J. (2018). Evaluation of the addition of organic acids in the feed and/or water for broilers and the subsequent recovery of Salmonella Typhimurium from litter and ceca. Poult Sci. 97(1): 64-73. doi: https://doi.org/10.3382/ps/ pex289

Cano, J.; Carcelén, F.; Ara, M.; Quevedo, W.; Alvarado, A.; Jiménez, R. (2016). Efecto de la suplementación con una mezcla probiótica sobre el comportamiento productivo de cuyes (Cavia porcellus) durante la fase de crecimiento y acabado. Rev Inv Vet Perú. 27(1): 51-58. doi: http://dx.doi.org/10.15381/rivep.v27i1.11458

Chuquizuta, C.; Morales, S. (2017). Identificación de agentes bacterianos patógenos aislados de gazapos muertos de cuyes en una granja de crianza intensiva en Lima, Perú. Rev. Electrón. Vet. 18(12): 1-13.

Dittoe, D.K.; Ricke, S.C.; Kiess, A.S. (2018). Organic Acids and Potential for Modifying the Avian Gastrointestinal Tract and Reducing Pathogens and Disease. Front. Vet. Sci. 5: 216. doi: https:// doi.org/10.3389/fvets.2018.00216
Gonzáles, S.; Icochea, E.; Reyna, P.; Guzmán, J.; Cazorla, F.; Lúcar, J.; Carcelén, F.; San Martin, V. (2013). Efecto de la suplementación de ácidos orgánicos sobre los parámetros productivos en pollos de engorde. Rev. Inv. Vet. Perú. 24 (1): 32-37.

Guevara, J.; Tapia, N.; Condorhuamán, C.; Díaz, P.; Carcelén, F.; Peña, D. (2015) Efecto del probiótico nativo del cuy (Cavia porcellus) suplementado a las madres sobre el peso de las crías al nacimiento y al destete. Rev. Per. Quím. Ing. Quím. 18(2): 73 - 77.

Grecco, H.A.T.; Amorim, A.B.; Saleh, M.A.D.; Tse, L.P.M.; Telles, F.G.; Miassi, G.M.; Pimenta, G.M.; Berto, D.A. (2018). Evaluation of growth performance and gastro-intestinal parameters on the response of weaned piglets to dietary organic acids. $A n$. Acad. Bras. Cienc. 90(1): 401-14. doi: https://doi. org/10.1590/0001-3765201820160057

INEI - Instituto Nacional de Estadistica e Informática (2017). Compendio estadístico Lima provincias 2016. Lima: INEI. 588p.

Jiménez, R.; Huamán, R. (2010). Manual para el manejo de reproductores híbridos especializados en producción de carne. Mantaro, Perú: Instituto Veterinario de Investigaciones Tropicales y de Altura Universidad Nacional de San Marcos. $175 p$.

Ke, W.C.; Ding, W.R.; Xu, D.M.; Ding, L.M.; Zhang, P.; Li, F.D.; Guo, X.S. (2017). Effects of addition of malic or citric acids on fermentation quality and chemical characteristics of alfalfa silage. J. Dairy. Sci. 100(11): 8958-8966. doi: https://doi. org/10.3168/jds.2017-12875

Liu, Y.; Espinosa, C.; Abelilla, J.; Casas, G.; Lagos, V.; Lee, S.; Kwon, W.; Mathai, J.; Navarro, D.; Jaworski, N.; Steinb, H. (2018). Non-antibiotic feed additives in diets for pigs: A review. Anim Nutr. 4(2): 113-125. doi: https://doi.org/10.1016/j. aninu.2018.01.007

Matsuura, A.; Morales, S.; Calle, E.; Ara, M. (2010). Susceptibilidad a antibacterianos in vitro de Salmonella enterica aislada de cuyes de crianza familiar-comercial en la provincia de Carhuaz, Ancash. Rev Inv Vet Perú. 21(1): 93-99. 
Morales, S.; Mattos, J.; Calle, S. (2013). Efecto de la muña (Satureja parvifolia) en la dinámica de la infección por Salmonella entérica en cobayos. Rev. Científica 10 (2): 123-134.

Morales, S. (2012). Patógenos oportunistas por transmisión fecal-oral en cuyes reproductores introducidos al distrito de San Marcos. Científica. 9 (1): 33-38.

Morales, S. (2017). Patógenos bacterianos y parasitarios más frecuentes en cuyes de crianza familiar - comercial en tres distritos de la Provincia de Bolognesi, Departamento de Ancash en época de seca. Lima, Perú: Universidad Nacional Mayor de San Marcos.

Morales-Cauti, S. (2018). Enfermedades emergentes en la producción de cuyes en el Perú; en: XLI Reunión Científica Anual APPA. Lima: Asociación Peruana de Producción Animal.

Ruggeri, J.; Foresti, F.; Pavesi, R.; Terrini, A.; Giudici, F.; Padoan, D.; Corradi, A., Ossiprandi, M.C.; Pasquali, P.; Alborali, G.L. (2018). The synergistic effect of organic acids, phytochemicals and a permeabilizing complex reduces Salmonella Typhimurium 1,4,[5],12:i-shedding in pigs. Vet Res Commun. 42(3):209-217. doi: https://doi. org/10.1007/s11259-018-9723-3

Sánchez-Silva, M.; Carcelén, F.; Ara, M.; Gonzales, R.; Quevedo, W.; Jiménez, R. (2014). Efecto de la suplementación de ácidos orgánicos sobre parámetros productivos del cuy (cavia porcellus). Rev Inv Vet Perú 25(3): 381-389.

Suryanarayana, A.; Suresh, J.; Rajasekhar, M. (2012). Organic acids in swine feeding a review. Agric. Sci. Res. J. 2(9): 523- 533.

Upadhaya, S.D.; Lee, K.Y.; Kim, I.H. (2014). Protected Organic Acid Blends as an Alternative to Antibiotics in Finishing Pigs. Asian-Australas $J$ Anim Sci. 27(11): 1600-1607. doi: https://doi. org/10.5713/ajas.2014.14356

Vargas, M.; Chávez, A.; Pinedo, R.; Morales, S.; Suarez, F. (2014). Parasitismo gastrointestinal en dos épocas del año en cuyes (Cavia porcellus) de Oxapampa, Pasco. Rev Inv Vet Perú. 25(2): 276 283.
Waldroup, A.; Kaniawati, S.; Mauromoustakos, A. (1995). Performance Characteristics and Microbiological Aspects of Broilers Fed Diets Supplemented with Organic Acids. J Food Prot. 58(5): 482-489. doi: https://doi. org/10.4315/0362-028X-58.5.482.

Xiong, X.; Tan, B.; Song, M.; Ji, P.; Kim, K.; Yin, Y.; Liu, Y. (2019). Nutritional Intervention for the Intestinal Development and Health of Weaned Pigs. Front Vet Sci. 6: 46. doi: https://doi.org/10.3389/ fvets.2019.00046 